удк 355.233.2.37.035.6

Ірина Чистякова
Сумський державний педагогічний
університет імені A. C. Макаренка
ORCID ID 0000-0001-8645-510X
Інна Драга
Сумський державний педагогічний
університет імені A. С. Макаренка
ORCID ID 0000-0002-0385-1957
0.24139/2312-5993/2020.02/196-205

\title{
ПІДГОТОВКА ВІЙСЬКОВОСЛУЖБОВЦІВ У ЗАКЛАДХ ВИЩОї ОСВІТИ УКРАїНИ
}

у статті з'ясовано особливості підготовки військовослужбовців у закладах вищої освіти Україні. Визначено головні критерії до вимог освіти. Окреслено основні світові тенденції розвитку військової освіти. Доведено, що військове навчання й виховання - це двоєдиний процес, метою якого є підготовка свідомих і вмілих захисників нашої Батьківщини, формування в них високих бойових та моральних якостей, злагодження підрозділів, частин, з'єднань і зрештою - підвищення боєздатності й боєготовності Збройних Сил країни. Суттєвою особливістю військово-педагогічного процесу $\epsilon$ те, що він здійснюється в нерозривній єдності зі службовою діяльністю військовослужбовців і має яскраво виражений практичний характер.

Ключові слова: військова освіта, підготовка військовослужбовців, заклади вищої освіти, військові заклади вищої освіти, освітній процес у військових закладах вищої освіти, Україна.

Постановка проблеми. Однією зі стратегічних загальнонаціональних функцій державної політики $€$ захист держави. У Конституції України наголошується, що «оборона України, захист ії суверенітету, територіальної цілісності й недоторканності покладаються на Збройні Сили України, а забезпечення державної безпеки й захист державного кордону України покладаються на відповідні військові формування та правоохоронні органи держави» (ст. 17 Конституції України).

Події на сході України розкрили цілу низку проблем у системі підготовки офіцерських кадрів. 3 оголошенням часткової мобілізації Держава Україна зіткнулася з таким явищем: з одного боку - високе патріотичне та морально-психологічне піднесення й готовність громадян стати на захист Батьківщини, а з іншого - низький військовий вишкіл, особливо молоді, яка не проходила військову службу. У зв'язку з цим, можемо стверджувати, що сучасне становище української армії вимагає негайної розробки та реалізації радикальних заходів для: моральнопсихологічного забезпечення військовослужбовців, змоги застосування на практиці отриманих знань, інноваційних підходів до проведення польових навчань із використанням традиційних і нетрадиційних форм ведення навчального бою, максимально наближених до бойових умов. 
У такому контексті важливого значення має процес підготовки військовослужбовців у закладах вищої освіти України.

Аналіз актуальних досліджень. Проблема підготовки військовослужбовців достатньо представлена в науковій літературі. Зокрема, велика увага акцентується на підготовці військових фахівців для збройних сил України (М. Нещадим, Ю. Приходько та ін.), Сполучених Штатів Америки (С. Владимирова, В. Іващенко та ін.), Китая (Б. Горбачов); Німеччини (В. Лазукін, Ю. Федосєєв та ін.), Великої Британії (М. Гацко та ін.); Франції (П. Колесов, А. Стрелецький, М. Сімаков та ін.), Туреччини (А. Федин), Італії (К. Колчин та ін.), Польщі (О. Мітягін, Ю. Приходько, О. Черних, Ю. Черних та ін.). Зарубіжні й вітчизняні науковці торкалися питань створення освітніх структур для підготовки військовослужбовців, їх функціонування, взаємодії з цивільними університетами, інститутами та коледжами.

Мета статті - з'ясувати особливості підготовки військовослужбовців у закладах вищої освіти Україні.

Методи дослідження. Для реалізації мети дослідження використано такі методи: загальнонаукові - аналіз, синтез, абстрагування, порівняння та узагальнення, що дали змогу з'ясувати особливості підготовки військовослужбовців у закладах вищої освіти Україні.

Виклад основного матеріалу. Офіцери Збройних сил України вирішують складні, різні й водночас украй необхідні для нашого суспільства завдання. Проаналізувавши характер їх діяльності та функціональні обов'язки, можемо стверджувати, що офіцерський склад концентрує важливі педагогічні функції, і $\epsilon$, водночас, учителем, вихователем і організатором військово-педагогічного процесу у військових підрозділах і частинах, що вимагає від них військово-професійних знань, сильного духу, необхідних професійних навичок і вмінь, високих особистісних індивідуально-психічних якостей.

У результаті аналізу й узагальнення світового досвіду здійснення підготовки військовослужбовців у закладах вищої освіти вітчизняні науковці І. Толок та Ю. Приходько визначили головні критерії вимог до військової освіти. На їх думку, державі потрібні висококваліфіковані військові фахівці, здатні керувати військами (силами) в бою (операції), навчанням, вихованням, розвитком, психологічною підготовкою особового складу в мирний і воєнний час; створювати, експлуатувати й застосовувати найскладніші системи озброєння та військової техніки; супроводжувати та здійснювати фундаментальні, прикладні дослідження; організовувати, проводити й контролювати дослідно-конструкторські роботи 3 випереджального створення нових поколінь озброєння, військової та спеціальної техніки; ефективно діяти під час виконання завдань, які виникають у процесі здійснення міжнародних антитерористичних і миротворчих операцій, участі в ліквідації локальних воєнних конфліктів (Толок та Приходько, 2013). 
М. Нещадим у своїй монографії «Військова освіта в Україні: історія, теорія, методологія, практика» тлумачить військову освіту як ступеневу систему неперервного навчання військових фахівців від початкової військової підготовки молоді до навчання офіцерів оперативностратегічного рівня. До того ж учений запропонував структуру підготовки військових фахівців. Він вважає, що підготовка військовослужбовців складається 3: початкової військової підготовки молоді; професійної військової підготовки; вищої освіти військових фахівців; підвищення кваліфікації й перепідготовки офіцерських кадрів (Нещадим, 2003).

Дослідження вітчизняних науковців та нормативно-правових документів питання виокремлення основних компонентів системи військової освіти показали, що до таких компонентів належать: органи управління військовою освітою; мережа закладів військової освіти (університети, академії, військові інститути, у тому числі в складі цивільних університетів, військові коледжі, факультети та кафедри військової підготовки, а також військові ліцеї й ліцеї $з$ посиленою військово-фізичною підготовкою); стандарти освітньої діяльності та стандарти освіти (професійний стандарт); рівні і ступені кваліфікації освіти (галузева рамка кваліфікацій); галузі знань, спеціальності і спеціалізації; освітньо-професійні (освітньо-наукові) програми; учасники освітнього процесу; законодавча та нормативно-правова база (Телелим, 2013; Про вищу освіту: Закон України; Зельницький, 2017; Фінін, 2020).

На сайті Міністерства оборони України представлено схематичне зображення структури системи військової освіти (рис. 1).

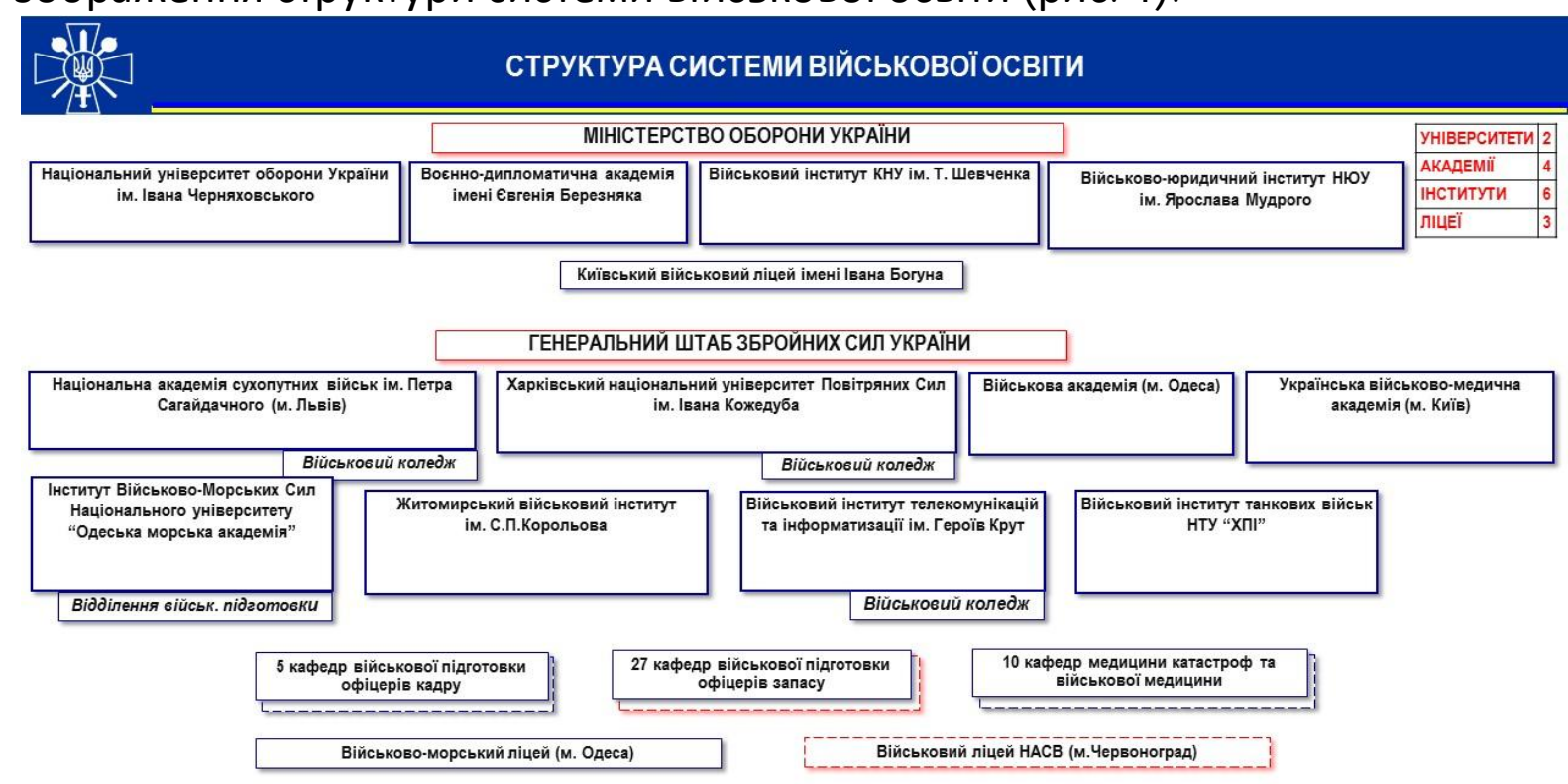

Рис. 1. Схема структури системи військової освіти України Джерело (Військова освіта та наука)

У контексті даної наукової розвідки вважаємо за необхідне звернути увагу на нормативно-правове забезпечення досліджуваної галузі освіти. Відтак, правовою основою військової освіти $є$ передусім Конституція України, 
Закон України «Про вищу освіту», Національна стратегія розвитку освіти в Україні на період до 2021 року, Національна доктрина розвитку освіти, Стратегія національно-патріотичного виховання дітей та молоді на 2016- 2020 роки, Національна рамка кваліфікацій, законодавчі акти України з питань оборони й національної безпеки, зокрема Воєнна доктрина України, Стратегія національної безпеки України, Указ Президента України «Про рішення Ради національної безпеки і оборони України від 4 березня 2016 року «Про Концепцію розвитку сектору безпеки і оборони України», Указ Президента України «Про рішення Ради національної безпеки і оборони України від 20 травня 2016 року «Про Стратегічний оборонний бюлетень України» та інші нормативно-правові акти України.

На сучасному етапі розвитку нашої держави, на наш погляд, у процесі підготовки військовослужбовців усе більшого значення набувають військові заклади вищої освіти.

Так, у «Положенні про вищі військові навчальна заклади» зазначається, що Вищий військовий навчальний заклад (ВВНЗ) - вищий навчальний заклад державної форми власності, який здійснює на певних рівнях вищої освіти підготовку, перепідготовку й підвищення кваліфікації військових фахівців для подальшої служби на посадах офіцерського (сержантського, старшинського) або начальницького складу 3 метою задоволення потреб збройних Сил України, інших утворених відповідно до законів України військових формувань, проводить наукову, науковотехнічну, інноваційну та/або методичну діяльність (Про затвердження Положення про вищі військові навчальні заклади).

У Положенні також визначено основні завдання ВВН3, крім визначених у статті 26 Закону України «Про вищу освіту». До них відненсено:

- провадження освітньої діяльності, що забезпечує підготовку військових фахівців відповідного ступеня вищої освіти за обраними ними спеціальностями;

- для університетів, академій, інститутів - провадження наукової діяльності в інтересах Збройних Сил України шляхом проведення наукових досліджень і забезпечення творчої діяльності учасників освітнього процесу, підготовки наукових кадрів вищої кваліфікації й використання отриманих результатів в освітньому процесі;

- виконання державного замовлення на підготовку військових фахівців, міжнародних договорів про підготовку військових фахівців іноземних держав;

- здійснення військової підготовки студентів вищих навчальних закладів та громадян України, які вже мають вищу освіту не нижче освітнього ступеня «бакалавр», за програмою підготовки офіцерів запасу;

- здійснення підготовки цивільних осіб за кошти фізичних осіб;

- проведення військово-патріотичного виховання молоді (Про затвердження Положення про вищі військові навчальні заклади). 
Як зазначає М. Нещадим, головними цілями системи військової освіти $€$ забезпечення ефективної підготовки військових кадрів відповідно до соціально-державного замовлення; зміцнення обороноздатності держави та морально-психологічного потенціалу ЗС України; внесок у фундаментальну, прикладну і військову науку та їі науково-методичну складову; удосконалення нормативно-правової бази системи військової освіти; підвищення якості управління освітою; оптимізацію мережі військових навчальних закладів і науково-методичних установ; збереження в армії і на флоті кращих традицій та започаткування нових; формування позитивного громадського ставлення до 3С; забезпечення компенсації фінансових витрат на утримання системи військової освіти (Нещадим, 2003).

В «Інструкції про організацію освітньої діяльності у вищих військових навчальних закладах Збройних Сил України та військових навчальних підрозділах вищих навчальних закладів України» констатовано, що освітня діяльність у вищих військових навчальних закладах реалізується у вигляді навчально-виховного процесу, охоплює навчальну, виховну, методичну роботу та наукову й науково-технічну діяльність... Навчально-виховний процес у вищих військових навчальних закладах забезпечує можливість здобуття студентами, курсантами знань, умінь і навичок у гуманітарній, соціальній, науково-природничій, технічній та військовій сферах, необхідних для професійної діяльності, та їх інтелектуального, морального, духовного, естетичного й фізичного розвитку (Інструкція). Цей керівний документ свідчить про нерозривний зв'язок навчального й виховного процесу у вищій військовій школі. Це закономірність, що притаманна всій освітянській сфері України. Готуючи фахівців, заклади вищої освіти формують громадянську свідомість і відповідальність перед Батьківщиною. Військові заклади освіти $\epsilon$ складником системи вищої освіти.

У контексті даної статті вважаємо за необхідне закцентувати увагу на основних принципіх виховної роботи та принципах навчання, які покладено в основу освітнього процесу військових закладів вищої освіти.

Основними принципами виховної роботи на підставі аналізу наукової літератури з проблеми дослідження та практичної діяльності військових закладів вищої освіти України нами визначено такі:

- державна й патріотична спрямованість виховного процесу;

- взаємозалежність змісту, форм і методів виховної роботи;

- повага до особистості, конституційних прав і свобод військовослужбовця, орієнтація на ідеали демократії та гуманізму, загальнолюдські моральні цінності;

- безперервність та спадкоємність у виховній роботі, органічне поєднання у виховному процесі національних, історичних та культурних традицій із почуттям нового;

- конкретність і узгодженість змісту, форм і методів виховної роботи; 
- об'єктивно-науковий підхід до планування, здійснення та оцінки результатів виховної роботи.

До того ж, зазначимо, що завдання виховної роботи визначаються положеннями про органи виховної роботи на основі Концепції виховної роботи у Збройних Силах та інших військових формуваннях України (Про Концепцію виховної роботи у збройних Силах та інших військових формуваннях України).

Відповідно, основними принципами військового навчання виокремлюємо такі:

- вчити війська тому, що необхідно на війні;

- свідомість, активність і самостійність навчання;

- наочність у навчанні;

- систематичність, послідовність і комплексність у навчанні;

- навчання на високому рівні труднощів;

- міцність оволодіння знаннями, уміннями й навичками;

- колективізм та індивідуальний підхід у навчанні.

Логіка дослідження вимагає звернення до наукових напрацювань вітчизняного вченого С.Полторака, предметом розгляду яких стали державно-управлінські аспекти розвитку системи вищої військової освіти України та за кордоном. Науковець зазначає, що для України є корисним урахування основних тенденцій розвитку сучасної системи військової освіти за кордоном, а саме:

-системний підхід до організації та здійснення підготовки офіцерських кадрів;

- розвинена інфраструктура системи підготовки офіцерських кадрів;

- підпорядкованість військових закладів вищої освіти командувачам видів військ;

- багатоступеневість військової підготовки;

- використання спеціалізованих навчальних центрів;

- підготовка військових фахівців відповідно до реальних потреб військ як у мирний, так і військовий час;

- підвищення кваліфікації протягом усієї військової служби;

- створення потужних університетів, навчально-наукових комплексів шляхом об'єднання окремих військових закладів вищої освіти;

- забезпечення престижності навчання, поваги до історії, традицій;

- фундаменталізація, гуманізація, демократизація, інформатизація й технологізація освітнього процесу;

- упровадження системи управління якістю освіти (Полторак, 2016).

До того ж, С. Полторак закцентовує на тому, що військова освіта України має враховувати основні світові тенденції інноваційного розвитку освіти й освітніх систем. У результаті аналізу наукових напрацювань в означеній сфері до загальних світових тенденцій розвитку освіти та освітніх систем він відносить такі: 
- синергетизація освіти;

- освіта протягом усього життя;

- випереджальна спрямованість освіти;

- інтеграція військової освіти та науки;

- фундаменталізація освіти;

- інформатизація освіти;

- глобалізація освіти;

- гуманізація;

- демократизація, стандартизація й технологізація освіти, забезпечення ії якості;

- особистісна спрямованість освіти тощо.

У цьому контексті вчений визначає пріоритетні напрями функціонування систем військової освіти в Україні. До них він відносить: стратегічні напрями; нормативно-правове забезпечення; мережу військових закладів освіти; управління військовою освітою; зміст військової освіти; організація навчального процесу та повсякденної діяльності; особистісна орієнтованість військової освіти (Полторак).

Висновки та перспективи подальших наукових досліджень. Таким чином, військове навчання й виховання - це двоєдиний процес, метою якого $\epsilon$ підготовка свідомих і умілих захисників нашої Батьківщини, формування в них високих бойових і моральних якостей, злагодження підрозділів, частин, з'єднань і зрештою - підвищення боєздатності й боєготовності Збройних Сил країни.

Суттєвою особливістю військово-педагогічного процесу $\epsilon$ те, що він здійснюється в нерозривній єдності зі службовою діяльністю військовослужбовців і носить яскраво виражений практичний характер. Отримувані військовослужбовцями знання, навички й уміння в процесі навчання відразу ж застосовуються під час несення бойового чергування, виконанні регламентованих робіт, бойових завдань тощо.

Отже, матеріали публікації дають можливість стверджувати про незаперечну актуальність та доцільність обраної проблеми й свідчать про наявність низки питань, які потребують більш повного висвітлення, зокрема, - у напрямі вивчення світового досвіду здійснення військової підготовки майбутніх фахівців військової справи в закладах вищої освіти, зокрема досвіду Польщі.

\section{ЛІТЕРАТУРА}

Військова освіта та наука. Режим доступу: https:// www.mil.gov.ua/ diyalnist/vijskovaosvita-na-tauka/ (Military education and science. Retrieved from: https:// www.mil.gov.ua/ diyalnist/vijskova-osvita-na-tauka/).

Зельницький, А. М. (2017). Якість вищої військової освіти як результат функціонування педагогічної системи ВВН3. Військова освіта, 1, 62-69. Режим доступу: http://nbuv.gov.ua/UJRN/vios_2017_1 11 (Zelnytskyi, A. M. (2017). The quality of higher military education as a result of the functioning of the pedagogical system of 
higher education institutions. Military Education, 1, 62-69. Retrieved from: http://nbuv.gov.ua/UJRN/vios 2017_1_11).

Інструкція про організацію освітньої діяльності у вищих військових навчальних закладах Збройних Сил України та військових навчальних підрозділах вищих навчальних закладів україни. Режим доступу: https://zakon.rada.gov.ua/laws/show/z0574-05 (Instruction on the organization of educational activities in higher military education institutions of the Armed Forces of Ukraine and military educational units of higher education institutions of Ukraine. Retrieved from: https://zakon.rada.gov.ua/laws/show/z0574-05).

Нещадим, М. І. (2003). Військова освіта в Україні: історія, теорія, методологія, практика. К.: Київський університет (Neshchadym, M. I. (2003). M ilitary education in Ukraine: history, theory, methodology, practice. K.: Kyiv University).

Полторак, С. Т. (2016). Розвиток системи вищої військової освіти України та за кордоном: державноуправлінські аспекти. Інвестиції: практика та досвід, 3, 70-73 (Poltorak, S. T. (2016). Development of the system of higher military education in Ukraine and abroad: public administration aspects. Investments: Practice and Experience, 3, 70-73).

Полторак, С. Т. Перспективні напрямки розвитку державного управління системою вищої військової освіти України. Режим доступу: https://nuczu.edu.ua/sciencearchive/PublicAdministration/vol7(17)/38.pdf

(Poltorak, S. Perspective directions of development of public administration of the high military education system in Ukraine. Retrieved from: https://nuczu.edu.ua/sciencearchive/PublicAdministration/vol7(17)/38.pdf).

Про вищу освіmу: Закон України від 01.07.2014 No1556-VII. Режим доступу: http://zakon4.rada.gov.ua/laws/show/1556-18/ page2 (On higher education: Law of Ukraine dated 01.07.2014 No. 1556-VII. Retrieved from: http:// zakon4.rada.gov.ua/laws/show/1556- 18/ page2).

Про затвердження Положення про вищі військові навчальні заклади. Режим доступу: https://zakon.rada.gov.ua/laws/show/z0706-15 (On approval of the Regulations on higher military education institutions. Retrieved from: https:// zakon.rada.gov.ua/laws/ show/z0706-15).

Про Концепцію виховної роботи у збройних Силах та інших військових формуваннях України. Режим доступу: httр://search.ligazakon.ua/l doc2.nsf/link1/U981 98.html (About the Concept of educational work in the Armed Forces and other military formations of Ukraine. Retrieved from: http://search.ligazakon.ua/I_doc2.nsf/link1/U981_98.html).

Телелим, В. М. (2013). Підготовка військових фахівців в контексті сучасних форм і видів збройної боротьби. Збірник наукових праць Військового інституту Київського національного університету ім. Тараса Шевченка, 42, 198-199 (Telelym, V. M. (2013). Training of military specialists in the context of modern forms and types of armed struggle. Collection of scientific works of the Military Institute of Kyiv National University. Taras Shevchenko, 42, 198-199).

Толок, І. В., Приходько, Ю. І. (2013). Підготовка військових фахівців з вищою освітою: інноваційні підходи. Педагогічні науки: теорія, історія, інноваційні технології, 6 (32), 259-269 (Tolok, I. V., Prykhodko, Yu. I. (2013). Training of military specialists with higher education: innovative approaches. Pedagogical sciences: theory, history, innovative technologies, 6 (32), 259-269).

Фінін, Г. І. (2020). Спеціфика становлення національної системи військової освіти: модернізація або реформування. Вісник Національного юридичного 
університету імені Ярослава Мудрого, 1 (44), 120-131. DOI: https:// doi.org/10.21564/2075-7190.44.195898 (Finin, H. I. (2020). Specificity of the national system of military education establishment: modernization and reform. Bulletin of the National Law University named after Yaroslav M udryi, 1 (44), 120-131. DOI: https://doi.org/10.21564/2075-7190.44.195898).

\section{PEЗЮME}

Чистякова Ирина, Драга Инна. Подготовка военнослужащих в учреждениях высшего образования в Украине.

В статье выяснены особенности подготовки военнослужащих в учреждениях высшего образования Украины. Определены главные критерии к требованиям образования. Определены основные мировые тенденции развития военного образования. Доказано, что военное обучение и воспитание - это двуединый процесс, целью которого является подготовка сознательных и умелых защитников нашей Родины, формирование у них высоких боевых и моральных качеств, слаживание подразделений, частей, соединений и наконец - повышение боеспособности и боеготовности Вооруженных Сил страны. Существенной особенностью военно-педагогического прочесса является то, что он осуществляется в неразрывном единстве со служебной деятельностью военнослужащих и носит ярко выраженный практический характер.

Ключевые слова: военное образование, подготовка военнослужащих, высшие учебные заведения, военные учреждения высшего образования, образовательный процесс в военных учреждениях высшего образования, Украина.

\section{SUMMARY}

Chystiakova Iryna, Draha Inna. Training of military personnel in higher education institutions in Ukraine.

The article clarifies the features of the military personnel training in higher education institutions of Ukraine. The main criteria for educational requirements are identified. The main global trends in the development of military education are determined. It is proved that military training and education is a two-fold process, the purpose of which is to train the conscious and skillful defenders of our M otherland, to form high military and moral qualities in them, to harmonize units, formations and, finally, to increase the combat readiness of the Armed Forces of the country. An essential feature of the military pedagogical process is that it is carried out in inextricable unity with the service activities of the military one and is of a pronounced practical nature.

To achieve the aim of the study, the following research methods were used: general scientific - analysis, synthesis, abstraction, comparison and generalization, which allowed to clarify the features of military personnel training in higher education institutions of Ukraine.

It is proved that it is useful for Ukraine to take into account the main trends in the development of the modern system of military education abroad, namely: a systems approach to the organization and implementation of military personnel training; developed infrastructure of the military personnel training system; subordination of military institutions of higher education to commanders of military types; multilevel military training; use of specialized training centers; training of military specialists in accordance with real needs of troops in both peacetime and wartime; advanced training during the entire military service; creation of powerful universities, educational and scientific complexes by uniting separate military institutions of higher education; ensuring the prestige of education, respect for history, traditions; fundamentalization, humanization, democratization, informatization and technologization of the educational process; introduction of an education quality management system. 
Key words military education, training of military personnel, higher education institutions, military institutions of higher education, educational process in military institutions of higher education, Ukraine.

удк 378.011.3-051:004.738.5(043.3)

Володимир Шевченко

Національний педагогічний

університет імені М. П. Драгоманова

ORCID ID 0000-0002-8905-5483

DOI 10.24139/2312-5993/2020.02/205-215

\section{ПСИХОЛОГО-ПЕДАГОГІЧНІ ОСОБЛИВОСТІ ВИКОРИСТАННЯ КОМП'ЮТЕРНО-ОРІЕНТОВАНИХ СИСТЕМ НАВЧАННЯ ОХОРОНИ ПРАЦІ}

Сьогодні більшість освітніх установ зіштовхуються з організаційними, технічними й матеріальними труднощами під час організації навчання у сфері апаратного і програмного забезпечення комп'ютера на реальному устаткуванні зі встановленим на ньому програмним забезпеченням (ПЗ), експериментування з яким може призвести до збоїв або тимчасового припинення функкціонування устаткування. Часто під час проведення практичного заняття немає можливості виділити студентам комп'ютери для вивчення апаратних засобів, установки налаштування і тестування ПЗ конкретною групою студентів; у більшості випадків під час установки й налаштування Пз необхідною $\epsilon$ наявність повноважень адміністратора, які не надаються студентам, виходячи з необхідності забезпечення безпеки комп'ютерів та інформаційної мережі освітньої установи; установка і налаштування деякого ПЗ тривала в часовому проміжку операція.

Ключові слова: охорона праці, ЗВО, інформаційна технологія забезпечення безпечного виробництва (ІТ ОБП), безпека праці, ІКТ виробництво.

Постановка проблеми. Охорона праці - одна з найбільш гострих проблем сучасного суспільства, що має глобальний характер. Це обумовлено, у першу чергу тим, що до кінця XX - початку XXI ст. різко зросли масштаби промислового виробництва, пов'язані з появою нових технологій і відповідних видів трудової діяльності, збільшенням кількості підприємств тощо. У результаті значною мірою зросла кількість небезпечних виробничих об'єктів, великі промислові аварії на таких об'єктах не тільки призводять до руйнування, припинення виробничої діяльності й загибелі працівників, але і перетворюють величезні території на зони, непридатні або малопридатні для проживання.

Мета дослідження полягає у виокремленні та наведенні основоположних психолого-педагогічних особливостей використання комп'ютерно-орієнтованих систем навчання, зокрема в сфері охорони праці.

Для вирішення та досягнення мети дослідження використано такі методи дослідження:

- теоретичні: теоретичний аналіз філософської, психологопедагогічної, науково-методичної і спеціальної літератури з проблеми дослідження, моделювання педагогічного процесу, узагальнення результатів дослідження з урахуванням конкретних умов і нових фактів; 